\title{
Antibiotic recommendations of office-based physicians, 2007-2011
}

\author{
Finley $\mathbf{R}^{1^{\star}}$ \\ ${ }^{1}$ Centre for Food-borne, Environmental and Zoonotic Infectious Diseases, Public Health Agency of Canada, Guelph, \\ ON \\ *Correspondence to: rita.finley@phac-aspc.gc.ca
}

\begin{abstract}
Objective: To describe patterns of antibiotic recommendations by office-based physicians from five regions in Canada between 2007 and 2011.

Methods: Values were estimated based on quarterly data from a sample of approximately 652 physicians stratified by region and specialty. For four consecutive quarters, each physician maintained a practice diary describing information on every patient visit during a randomly selected 48 -hour period. This information was then extrapolated using a projection factor to estimate prescriptions by all physicians across Canada.

Results: Over the five-year surveillance period, physicians saw patients for almost 1.5 billion diagnoses with approximately 120 million antimicrobial recommendations. In 2011 alone, 289 million clinical diagnoses were made of which $8 \%$ resulted in an antimicrobial being recommended. The majority of these $(51 \%)$ were for the treatment of diseases of the respiratory system, $14 \%$ for infections of the urinary tract, and $11 \%$ for diseases of skin and subcutaneous tissue. Antimicrobial recommendations were highest for patients in the age groups of $0-2,3-9$, and 65 or older. Antimicrobial recommendation rates generally decreased between 2007 and 2011 except for diseases of the genitourinary system and diseases of the ear that remained stable. Overall, the most commonly recommended antimicrobials included macrolides, penicillins with extended spectrum, and fluoroquinolones. Although not as common, there was a $42 \%$ increase in the number of physician recommendations for third generation cephalosporins.
\end{abstract}

Conclusion: With the exception of third generation cephalosporins, the percentage of antimicrobial recommendations by office-based physicians in Canada remained stable or decreased between 2007 and 2011. Provincial differences were observed in the antimicrobial recommendations and rates, with the Atlantic region and Québec having higher rates of antimicrobial recommendations compared to the overall national level.

\section{Introduction}

The Canadian Integrated Program for Antimicrobial Resistance Surveillance (CIPARS) monitors trends in antimicrobial use and antimicrobial resistance in selected bacterial organisms from human, animal and food sources across Canada. The Program is based on several representative and methodologically unified surveillance components that can be linked to examine the relationship between antimicrobials used in food animals and humans, and the associated health impacts. This information supports: (i) the creation of evidence-based policies to control antimicrobial use in hospital, community, and agricultural settings, and thus prolong the effectiveness of these drugs; and (ii) the identification of appropriate 
measures to contain the emergence and spread of resistant bacteria between animals, food, and people in Canada.

The human antimicrobial use surveillance reports are published on a regular basis to provide a national overview of current antimicrobial use practices in Canada annually, to enable comparisons and to support formulary and stewardship development. The objective of this paper is to summarize the most recent CIPARS report that describes patterns of antibiotic recommendations by office-based physicians from five regions in Canada between 2007 and 2011 (1).

\section{Methods}

The Canadian Disease and Therapeutic Index (CDTI) dataset is purchased by the Public Health Agency of Canada from IMS Health Canada Inc. This dataset provides information about the patterns and treatments of disease encountered by office-based physicians from five regions: Atlantic (New Brunswick, Newfoundland and Labrador, Nova Scotia, and Prince Edward Island), Québec, Ontario, the Prairies (Alberta, Manitoba, and Saskatchewan), and British Columbia. Values are estimated based on quarterly data from a sample of approximately 652 physicians stratified by region and specialty. For four consecutive quarters, each physician maintains a practice diary describing information on every patient visit during a randomly selected 48-hour period. This information is then extrapolated using a projection factor to estimate the "universe" comprised of approximately 52,959 physicians, roughly representing all Canadian data.

The information contained in this analysis is for antimicrobials for which a physician has provided a recommendation or prescription, and does not represent actual prescriptions dispensed by pharmacists or consumed by the patient. This data does not include patient visits to a primary care nurse, and diagnosis visits do not translate into the total number of patients, as some patients visited multiple times for the same reason or were diagnosed with multiple diseases. Due to the methods of data collection, sample size is sometimes considered too small for decision making. However, information is still included in this analysis to provide a view of practices which may require further study.

\section{Results}

Over the five-year surveillance period (2007-2011) physicians saw patients for almost 1.5 billion diagnoses and provided a total of approximately 121 million antimicrobial recommendations(1). In 2011, a total of 289 million clinical diagnoses were made of which $8 \%$ resulted in an antimicrobial recommendation (Table 1). During that year, out of all the antimicrobials recommended by office-based physicians, $51.3 \%$ were for treatment of diseases of the respiratory system followed by infections of the urinary tract $(14.5 \%)$ and diseases of the skin and subcutaneous tissue $(11.3 \%)$ 
TABLE 1. Total number of office-based diagnoses, diagnosis rate, total number of antimicrobial recommendations, antimicrobial recommendation rate, and percentage of diagnoses with antimicrobial recommendations by office-based physicians in Canada, by diagnostic class, 2011

\begin{tabular}{|c|c|c|c|c|c|}
\hline Diagnostic class & $\begin{array}{l}\text { Total } \\
\text { diagnoses }\end{array}$ & $\begin{array}{c}\text { Total diagnoses / } \\
10,000 \\
\text { inhabitants }\end{array}$ & $\begin{array}{l}\text { Antimicrobial } \\
\text { recommendation } \\
\text { S } \\
\text { (N) }\end{array}$ & $\begin{array}{l}\text { Total antimicrobial } \\
\text { recommendations / } \\
10,000 \text { inhabitants }\end{array}$ & $\begin{array}{c}\text { Percentage } \\
\text { diagnoses } \\
\text { with antimicrobia } \\
\text { recommendations }\end{array}$ \\
\hline $\begin{array}{c}\text { Complications of } \\
\text { pregnancy, } \\
\text { childbirth, and } \\
\text { puerperal }\end{array}$ & $1,044,850$ & 302 & 17,180 & 5 & 1.6 \\
\hline $\begin{array}{c}\text { Congenital } \\
\text { anomalies }\end{array}$ & 925,330 & 267 & 21,290 & 6 & 2.3 \\
\hline $\begin{array}{c}\text { Diseases of } \\
\text { blood/blood- } \\
\text { forming organs }\end{array}$ & $2,593,490$ & 749 & 45,160 & 13 & 1.7 \\
\hline $\begin{array}{c}\text { Diseases of skin } \\
\text { and subcutaneous } \\
\text { tissue }\end{array}$ & $21,784,200$ & 6,295 & $2,551,830$ & 737 & 11.7 \\
\hline $\begin{array}{c}\text { Diseases of the } \\
\text { central nervous } \\
\text { system }\end{array}$ & $10,591,580$ & 3,061 & 148,900 & 43 & 1.4 \\
\hline $\begin{array}{l}\text { Diseases of the } \\
\text { circulatory system }\end{array}$ & $33,884,750$ & 9,791 & 62,510 & 18 & 0.2 \\
\hline Diseases of the ear & $7,627,370$ & 2,204 & $2,232,080$ & 645 & 29.3 \\
\hline $\begin{array}{c}\text { Diseases of the } \\
\text { gastrointestinal } \\
\text { system }\end{array}$ & $1,674,160$ & 484 & 107,900 & 31 & 6.4 \\
\hline $\begin{array}{c}\text { Diseases of the } \\
\text { genitourinary } \\
\text { system }\end{array}$ & $12,878,470$ & 3,721 & 821,180 & 237 & 6.4 \\
\hline $\begin{array}{l}\text { Diseases of the } \\
\text { respiratory system }\end{array}$ & $37,079,860$ & 10,715 & $11,628,520$ & 3,360 & 31.4 \\
\hline $\begin{array}{c}\text { Endocrine, } \\
\text { nutritional, } \\
\text { metabolic, and } \\
\text { immunity diseases }\end{array}$ & $28,537,420$ & 8,246 & 62,310 & 18 & 0.2 \\
\hline $\begin{array}{l}\text { Infections of the } \\
\text { urinary tract }\end{array}$ & $6,951,220$ & 2,009 & $3,285,390$ & 949 & 47.3 \\
\hline $\begin{array}{l}\text { Injuries and } \\
\text { poisonings }\end{array}$ & $11,575,360$ & 3,345 & 317,020 & 92 & 2.7 \\
\hline $\begin{array}{c}\text { Musculoskeletal } \\
\text { diseases }\end{array}$ & $28,086,920$ & 8,116 & 136,030 & 39 & 0.5 \\
\hline Neoplasms & $7,124,130$ & 2,059 & 93,740 & 27 & 1.3 \\
\hline $\begin{array}{c}\text { Other diseases of } \\
\text { the digestive } \\
\text { system }\end{array}$ & $17,401,060$ & 5,028 & 684,730 & 198 & 3.9 \\
\hline $\begin{array}{l}\text { Perinatal } \\
\text { conditions }\end{array}$ & 438,380 & 127 & 14,540 & 4 & 3.3 \\
\hline $\begin{array}{l}\text { Supplementary } \\
\text { classifications }\end{array}$ & $37,076,290$ & 10,714 & 77,420 & 22 & 0.2 \\
\hline $\begin{array}{l}\text { Symptoms and ill- } \\
\text { defined conditions }\end{array}$ & $21,771,660$ & 6,291 & 359,500 & 104 & 1.7 \\
\hline Total & $289,046,500$ & 83,524 & $22,667,230$ & 6,550 & 7.8 \\
\hline
\end{tabular}

Antimicrobials were recommended to all age groups in 2011, with proportionally higher recommendation rates to patients in the age group 0-2 years (12 antimicrobial recommendations per 10 inhabitants); 3-9 years ( 9 antimicrobial recommendations per 10 inhabitants); and 60-64 years, and 65 years of age or older ( 7 antimicrobial recommendations per 10 inhabitants for each age group) (Table 2). 
TABLE 2. Diagnosis rate, antimicrobial recommendation rate and percentage of diagnosis with antimicrobial recommendation provided by office-based physicians in Canada, by age group and by gender, 2011

\begin{tabular}{|c|c|c|c|}
\hline $\begin{array}{c}\text { Demographics: } \\
\text { age (year) or } \\
\text { gender }\end{array}$ & $\begin{array}{c}\text { Number of } \\
\text { diagnoses } / 10 \\
\text { inhabitants }\end{array}$ & $\begin{array}{c}\text { Antimicrobial } \\
\text { recommendations } \\
/ 10 \text { inhabitants }^{2}\end{array}$ & $\begin{array}{c}\text { Percentage of diagnoses } \\
\text { with antimicrobial } \\
\text { recommendations }\end{array}$ \\
\hline Age & 123 & 12 & 9.7 \\
\hline 0 to 2 & 52 & 9 & 16.5 \\
\hline 3 to 9 & 42 & 6 & 13.0 \\
\hline 10 to 19 & 59 & 6 & 10.7 \\
\hline 20 to 39 & 81 & 5 & 6.6 \\
\hline 40 to 59 & 122 & 7 & 5.5 \\
\hline 60 to 64 & 152 & 7 & 4.9 \\
\hline 65 or older & & 7 & 7.7 \\
\hline Gender & 93 & 6 & 8.0 \\
\hline Female & 71 & & \\
\hline Male & & 75 & \\
\hline
\end{tabular}

${ }^{1}$ Diagnosis does not represent the number of times a person visits, but represents every time a diagnosis is provided; if a person presents multiple diseases each individual disease/diagnosis is recorded separately.

${ }^{2}$ Data does not represent actual prescriptions dispensed by pharmacists or products consumed by the patient, as information on patient compliance was not available.

For the most part, the percentage of antimicrobial recommendations by office-based physicians in Canada remained stable or decreased between 2007 and 2011 (Figure 1). Slight increases were seen related to complications of pregnancy, childbirth, and puerperal; congenital anomalies; diseases of the gastrointestinal system; injuries and poisonings; and perinatal conditions.

FIGURE 1. Percentage of diagnoses that received an antimicrobial recommendation by office-based physicians in Canada, 2007, 2010, and 2011

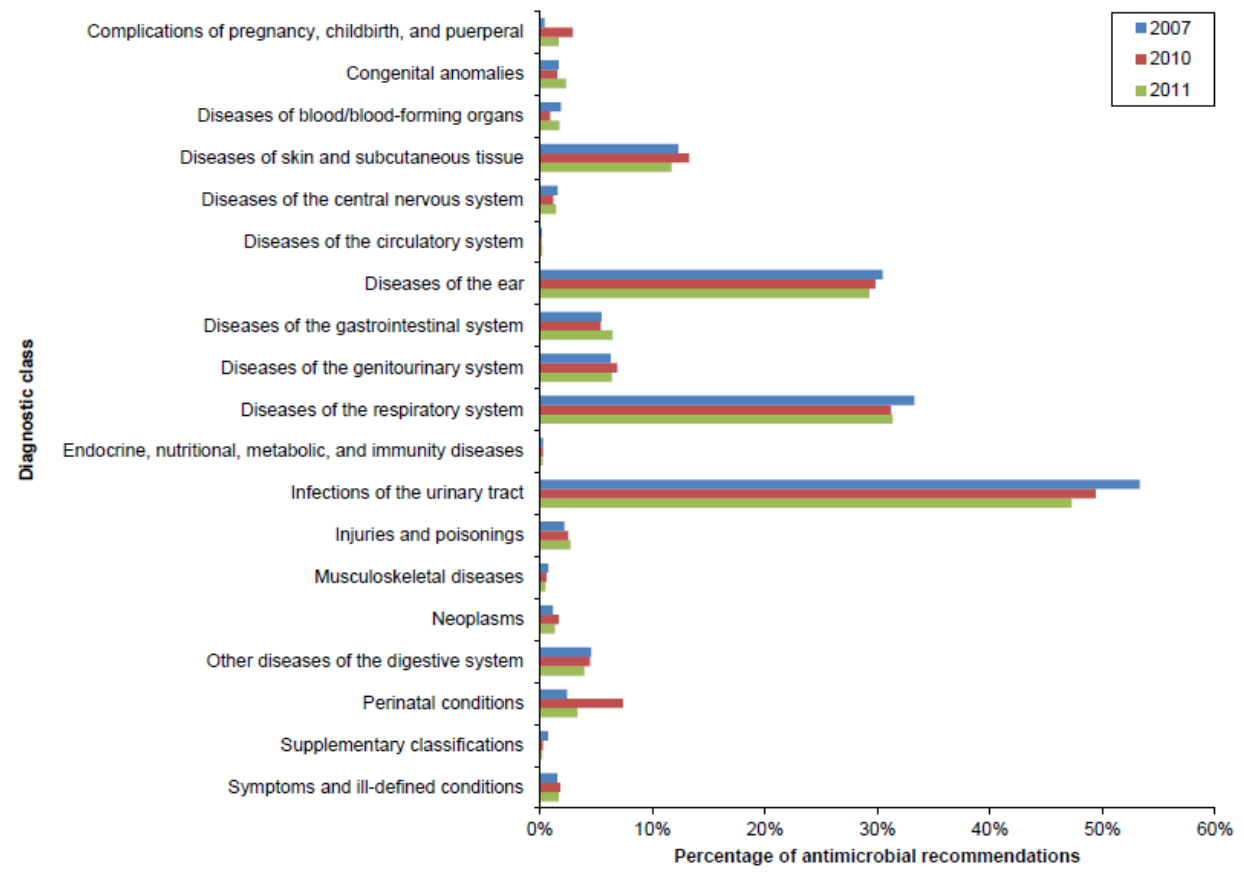


The most commonly recommended antimicrobials in 2011 were the macrolides $(1,638$ recommendations per 10,000 inhabitants), penicillins with extended spectrum (1,504 recommendations per 10,000 inhabitants), and the fluoroquinolones (1,202 recommendations per 10,000 inhabitants). However, high increases in the number of physician recommendations were observed for third generation cephalosporins (a 42\% increase compared to 2007) due to an increase in recommendations for treatment of diseases of the respiratory system, diseases of the genitourinary system, and infections of the urinary tract.

Provincial variation in the total number of antimicrobial recommendations per 10,000 inhabitants was observed, with the Atlantic region (7,101 recommendations per 10,000 inhabitants) and Québec (8,268 recommendations per 10,000 inhabitants) having the highest rates compared to the overall national level. Rates of diagnoses and antimicrobial recommendations per 10,000 inhabitants varied depending upon the province and disease of treatment. Provincial preferences for antimicrobial of choice for treatment of disease were also observed (Table 3).

TABLE 3. Diagnosis rate, antimicrobial recommendation rate and percentage of diagnoses with antimicrobial recommendations provided by office-based physicians in Canada, by diagnostic class and by province/region, 2011

\begin{tabular}{|c|c|c|c|c|}
\hline Diagnostic class & $\begin{array}{l}\text { Province / } \\
\text { region }\end{array}$ & $\begin{array}{c}\text { Number of } \\
\text { diagnoses / } \\
10,000 \\
\text { inhabitants }^{1}\end{array}$ & $\begin{array}{c}\text { Antimicrobial } \\
\text { recommendations } \\
/ 10,000 \\
\text { inhabitants }{ }^{2}\end{array}$ & $\begin{array}{l}\text { Percentage of } \\
\text { diagnoses with } \\
\text { antimicrobial } \\
\text { recommendations }\end{array}$ \\
\hline \multirow{6}{*}{$\begin{array}{l}\text { Complications of } \\
\text { pregnancy, childbirth, and } \\
\text { puerperal }\end{array}$} & $\begin{array}{l}\text { British } \\
\text { Columbia }\end{array}$ & 350 & $\mathrm{NAS}^{3}$ & NAS \\
\hline & Prairies $^{4}$ & 303 & 3 & 1.1 \\
\hline & Ontario & 271 & NAS & NAS \\
\hline & Quebec & 330 & 19 & 5.7 \\
\hline & Atlantic $^{5}$ & 298 & NAS & NAS \\
\hline & Total & 302 & 5 & 1.6 \\
\hline \multirow{6}{*}{ Congenital anomalies } & $\begin{array}{l}\text { British } \\
\text { Columbia }\end{array}$ & 374 & 10 & 2.7 \\
\hline & Prairies & 265 & 13 & 4.7 \\
\hline & Ontario & 171 & 5 & 2.9 \\
\hline & Quebec & 296 & NAS & NAS \\
\hline & Atlantic & 530 & 10 & 1.9 \\
\hline & Total & 267 & 6 & 2.3 \\
\hline \multirow{6}{*}{$\begin{array}{l}\text { Diseases of blood/blood- } \\
\text { forming organs }\end{array}$} & $\begin{array}{l}\text { British } \\
\text { Columbia }\end{array}$ & 715 & NAS & NAS \\
\hline & Prairies & 665 & 12 & 1.8 \\
\hline & Ontario & 744 & 20 & 2.7 \\
\hline & Quebec & 707 & 13 & 1.9 \\
\hline & Atlantic & 1,242 & NAS & NAS \\
\hline & Total & 749 & 13 & 1.7 \\
\hline \multirow{6}{*}{$\begin{array}{l}\text { Diseases of skin and } \\
\text { subcutaneous tissue }\end{array}$} & $\begin{array}{l}\text { British } \\
\text { Columbia }\end{array}$ & 7,602 & 820 & 10.8 \\
\hline & Prairies & 6,061 & 706 & 11.6 \\
\hline & Ontario & 5,866 & 792 & 13.5 \\
\hline & Quebec & 6,399 & 664 & 10.4 \\
\hline & Atlantic & 6,741 & 631 & 9.4 \\
\hline & Total & 6,295 & 737 & 11.7 \\
\hline \multirow{6}{*}{$\begin{array}{l}\text { Diseases of the central } \\
\text { nervous system }\end{array}$} & $\begin{array}{l}\text { British } \\
\text { Columbia }\end{array}$ & 3,472 & 73 & 2.1 \\
\hline & Prairies & 2,440 & 33 & 1.3 \\
\hline & Ontario & 3,297 & 39 & 1.2 \\
\hline & Quebec & 3,020 & 37 & 1.2 \\
\hline & Atlantic & 2,811 & 57 & 2.0 \\
\hline & Total & 3,061 & 43 & 1.4 \\
\hline $\begin{array}{l}\text { Diseases of the } \\
\text { circulatory system }\end{array}$ & $\begin{array}{l}\text { British } \\
\text { Columbia }\end{array}$ & 9,503 & 48 & 0.5 \\
\hline
\end{tabular}




\begin{tabular}{|l|r|r|r|} 
Prairies & 9,231 & 5 & 0.0 \\
\hline Ontario & 9,479 & 19 & 0.2 \\
\hline Quebec & 1,037 & 8 & 0.8 \\
\hline Atlantic & 12,081 & 24 & 0.2 \\
\hline Total & 9,792 & 18 & 0.2 \\
\hline
\end{tabular}

${ }^{1}$ Diagnosis does not represent the number of times a person visits, but represents every time a diagnosis is provided; if a person presents with multiple diseases each individual disease/diagnosis is recorded separately.

${ }^{2}$ Data does not represent actual prescriptions dispensed by pharmacists or products consumed by the patient, as information on patient compliance was not available.

${ }^{3} \mathrm{NAS}=$ no antimicrobials suggested (recommended).

${ }^{4}$ The Prairies include the provinces of Alberta, Saskatchewan, and Manitoba.

${ }^{5}$ The Atlantic region includes the provinces of New Brunswick, Nova Scotia, Prince Edward Island, and Newfoundland and Labrador.

TABLE 3 (continued). Diagnosis rate, antimicrobial recommendation rate and percentage of diagnoses with antimicrobial recommendations provided by office-based physicians in Canada, by diagnostic class and by province/region, 2011

\begin{tabular}{|c|c|c|c|c|}
\hline Diagnostic class & Province / region & $\begin{array}{l}\text { Number of diagnoses } \\
/ 10,000 \text { inhabitants }^{1}\end{array}$ & $\begin{array}{l}\text { Antimicrobial } \\
\text { recommendations / } \\
10,000 \text { inhabitants }^{2}\end{array}$ & $\begin{array}{l}\text { Percentage of } \\
\text { diagnoses with } \\
\text { antimicrobial } \\
\text { recommendations }\end{array}$ \\
\hline \multirow{6}{*}{ Diseases of the ear } & British Columbia & 2,285 & 349 & 15.3 \\
\hline & Prairies $^{4}$ & 1,628 & 460 & 28.2 \\
\hline & Ontario & 1,708 & 514 & 30.1 \\
\hline & Quebec & 3,123 & 1,168 & 37.4 \\
\hline & Atlantic $^{5}$ & 3,348 & 702 & 21.0 \\
\hline & Total & 2,204 & 645 & 29.3 \\
\hline \multirow{6}{*}{$\begin{array}{l}\text { Diseases of the gastrointestinal } \\
\text { system }\end{array}$} & British Columbia & 452 & 53 & 11.6 \\
\hline & Prairies & 521 & 9 & 1.7 \\
\hline & Ontario & 461 & 29 & 6.4 \\
\hline & Quebec & 530 & 28 & 5.3 \\
\hline & Atlantic & 445 & 69 & 15.6 \\
\hline & Total & 484 & 31 & 6.4 \\
\hline \multirow{6}{*}{$\begin{array}{l}\text { Diseases of the genitourinary } \\
\text { system }\end{array}$} & British Columbia & 3,646 & 207 & 5.7 \\
\hline & Prairies & 3,500 & 252 & 7.2 \\
\hline & Ontario & 3,606 & 218 & 6.0 \\
\hline & Quebec & 3,815 & 277 & 7.3 \\
\hline & Atlantic & 4,957 & 243 & 4.9 \\
\hline & Total & 3,722 & 237 & 6.4 \\
\hline \multirow{6}{*}{$\begin{array}{l}\text { Diseases of the respiratory } \\
\text { system }\end{array}$} & British Columbia & 9,699 & 2,649 & 27.3 \\
\hline & Prairies & 10,193 & 3,307 & 32.4 \\
\hline & Ontario & 9,687 & 3,000 & 31.0 \\
\hline & Quebec & 13,044 & 4,377 & 33.6 \\
\hline & Atlantic & 12,504 & 3,641 & 29.1 \\
\hline & Total & 10,715 & 3,360 & 31.4 \\
\hline \multirow{6}{*}{$\begin{array}{l}\text { Endocrine, nutritional, metabolic, } \\
\text { and immunity diseases }\end{array}$} & British Columbia & 7,353 & $\mathrm{NAS}^{3}$ & NAS \\
\hline & Prairies & 6,940 & 14 & 0.2 \\
\hline & Ontario & 8,557 & 23 & 0.3 \\
\hline & Quebec & 8,477 & 28 & 0.3 \\
\hline & Atlantic & 11,215 & 5 & $<0.1$ \\
\hline & Total & 8,247 & 18 & 0.2 \\
\hline \multirow{2}{*}{ Infections of the urinary tract } & British Columbia & 2,241 & 982 & 43.8 \\
\hline & Prairies & 1,886 & 825 & 43.8 \\
\hline
\end{tabular}




\begin{tabular}{|l|r|r|r|} 
Ontario & 1,869 & 855 & 45.7 \\
\hline Quebec & 1,891 & 1,143 & 60.5 \\
\hline Atlantic & 3,164 & 1,134 & 35.8 \\
\hline Total & 2,009 & 949 & 47.3 \\
\hline
\end{tabular}

${ }^{1}$ Diagnosis does not represent the number of times a person visits, but represents every time a diagnosis is provided; if a person presents with multiple diseases each individual disease/diagnosis is recorded separately.

${ }^{2}$ Data does not represent actual prescriptions dispensed by pharmacists or products consumed by the patient, as information on patient compliance was not available.

${ }^{3} \mathrm{NAS}=$ no antimicrobials suggested (recommended).

${ }^{4}$ The Prairies include the provinces of Alberta, Saskatchewan, and Manitoba.

${ }^{5}$ The Atlantic region includes the provinces of New Brunswick, Nova Scotia, Prince Edward Island, and Newfoundland and Labrador.

TABLE 3 (continued). Diagnosis rate, antimicrobial recommendation rate and percentage of diagnoses with antimicrobial recommendations provided by office-based physicians in Canada, by diagnostic class and by province/region, 2011

\begin{tabular}{|c|c|c|c|c|}
\hline Diagnostic class & Province / region & $\begin{array}{l}\text { Number of diagnoses } \\
/ 10,000 \text { inhabitants }^{1}\end{array}$ & $\begin{array}{l}\text { Antimicrobial } \\
\text { recommendations / } \\
10,000 \text { inhabitants }^{2}\end{array}$ & $\begin{array}{l}\text { Percentage of } \\
\text { diagnoses with } \\
\text { antimicrobial } \\
\text { recommendations }\end{array}$ \\
\hline \multirow{6}{*}{ Injuries and poisonings } & British Columbia & 5,400 & 99 & 1.8 \\
\hline & Prairies $^{4}$ & 3,446 & 93 & 2.7 \\
\hline & Ontario & 2,864 & 94 & 3.3 \\
\hline & Quebec & 3,221 & 90 & 2.8 \\
\hline & Atlantic $^{5}$ & 2,398 & 73 & 3.0 \\
\hline & Total & 3,345 & 92 & 2.7 \\
\hline \multirow{6}{*}{ Musculoskeletal diseases } & British Columbia & 8,402 & 4 & $<0.1$ \\
\hline & Prairies & 8,748 & 53 & 0.6 \\
\hline & Ontario & 7,911 & 56 & 0.7 \\
\hline & Quebec & 6,804 & 13 & 0.2 \\
\hline & Atlantic & 11,928 & 69 & 0.6 \\
\hline & Total & 8,116 & 39 & 0.5 \\
\hline \multirow{6}{*}{ Neoplasms } & British Columbia & 2,012 & 10 & 0.5 \\
\hline & Prairies & 1,630 & 3 & 0.2 \\
\hline & Ontario & 1,840 & 8 & 0.5 \\
\hline & Quebec & 2,645 & 95 & 3.6 \\
\hline & Atlantic & 2,614 & $\mathrm{NAS}^{3}$ & NAS \\
\hline & Total & 2,059 & 27 & 1.3 \\
\hline \multirow{6}{*}{$\begin{array}{l}\text { Other diseases of the digestive } \\
\text { system }\end{array}$} & British Columbia & 4,925 & 237 & 4.8 \\
\hline & Prairies & 5,460 & 138 & 2.5 \\
\hline & Ontario & 4,547 & 214 & 4.7 \\
\hline & Quebec & 4,962 & 224 & 4.5 \\
\hline & Atlantic & 7,311 & 106 & 1.5 \\
\hline & Total & 5,028 & 198 & 3.9 \\
\hline \multirow{6}{*}{ Perinatal conditions } & British Columbia & 123 & NAS & NAS \\
\hline & Prairies & 154 & 16 & 10.1 \\
\hline & Ontario & 151 & NAS & NAS \\
\hline & Quebec & 96 & 6 & 6.5 \\
\hline & Atlantic & 35 & NAS & NAS \\
\hline & Total & 127 & 4 & 3.3 \\
\hline \multirow{6}{*}{ Supplementary classifications } & British Columbia & 10,174 & 12 & 0.1 \\
\hline & Prairies & 12,776 & 9 & 0.1 \\
\hline & Ontario & 10,851 & 24 & 0.2 \\
\hline & Quebec & 9,323 & 37 & 0.4 \\
\hline & Atlantic & 10,867 & 21 & 0.2 \\
\hline & Total & 10,714 & 22 & 0.2 \\
\hline Symptoms and ill-defined & British Columbia & 6,427 & 97 & 1.5 \\
\hline
\end{tabular}


conditions

\begin{tabular}{|l|r|r|r|} 
Prairies & 5,819 & 68 & 1.2 \\
\hline Ontario & 6,666 & 123 & 1.9 \\
\hline Quebec & 4,792 & 41 & 0.9 \\
\hline Atlantic & 10,502 & 315 & 3.0 \\
\hline Total & 6,291 & 104 & 1.7 \\
\hline
\end{tabular}

${ }^{1}$ Diagnosis does not represent the number of times a person visits, but represents every time a diagnosis is provided; if a person presents with multiple diseases each individual disease/diagnosis is recorded separately.

${ }^{2}$ Data does not represent actual prescriptions dispensed by pharmacists or products consumed by the patient, as information on patient compliance was not available.

${ }^{3} \mathrm{NAS}=$ no antimicrobials suggested (recommended).

${ }^{4}$ The Prairies include the provinces of Alberta, Saskatchewan, and Manitoba.

${ }^{5}$ The Atlantic region includes the provinces of New Brunswick, Nova Scotia, Prince Edward Island, and Newfoundland and Labrador.

\section{Discussion}

Eight percent of clinical diagnoses provided by office-based physicians resulted in an antimicrobial being recommended in 2011. Of these, $51 \%$ were for the treatment of diseases of the respiratory system, followed by $14 \%$ for infections of the urinary tract, and $11 \%$ for diseases of skin and subcutaneous tissue. Antimicrobial recommendations were highest for patients in the age groups of $0-2$ years, 3-9 years, and 65 years or older. Antimicrobial recommendation rates decreased between 2007 and 2011 for diseases of the ear, the respiratory system, infections of the urinary tract, and diseases of the skin and subcutaneous tissue, while the rates for diseases of the genitourinary system remained stable.

Overall, the most commonly recommended antimicrobials included macrolides, penicillins with extended spectrum and fluoroquinolones. Provincial differences were observed in the antimicrobial recommendation rates and antimicrobial selected for treatment, with the Atlantic region and Québec having higher rates of antimicrobial recommendations compared to the national levels. British Columbia had the lowest rate of antimicrobial recommendations for diseases of the respiratory system, while Québec and the Atlantic region had the highest for diseases of the ear. The Prairies had the lowest rate of antimicrobial recommendations for infections of the urinary tract, but did observe an increase in these between 2010 and 2011. A similar rate of antimicrobial recommendations across the country was observed for diseases of the genitourinary system, while decreases in recommendations were observed across the country for diseases of the skin and subcutaneous tissue.

There are several limitations and caveats within the CDTI dataset. The drugs listed are those that the physician has written or recommended and do not represent actual prescriptions dispensed by pharmacists or products consumed by the patient, as information on patient compliance was not available. The data do not include patient visits to a primary care nurse, and diagnosis visits do not translate into number of patients as some patients may have visited multiple times for the same reason or were diagnosed with multiple diseases.

The appearance of a drug may include samples that do not necessarily tie to a prescription dispensed as physicians list all suggested treatments. Physicians also record drugs "previously ordered and continued" for the diagnosis, which would not necessarily tie to a prescription dispensed. In addition, some drug therapy and diagnosis is under-represented due to self-medication (i.e., over-the-counter products). Sample size is sometimes considered too small for decision making; however, these have been included for information purposes only and reliability of the data is dependent on sampling error, so caution should be taken when interpreting those disease categories with a small sample size. Data are only available at the regional level, where fluctuations may be more or less obvious and specific information for individual provinces could not be determined.

Antimicrobial resistance will continue to challenge the health of Canadians and those around the world for some time to come. Antibiotic use surveillance will help document the progress we have made in curbing it and the impact these changes might have had on overall antibiotic resistance. 


\section{Acknowledgements}

The author would like to acknowledge the external reviewers of the Human Antimicrobial Use Report: Dr. John Conly, Dr. Jim Hutchinson, Dr. Warren Mclsaac, Dr. David Patrick, Dr. Lynora Saxinger, Dr. Daniel Thirion, and Dr. Karl Weiss. Without their close collaboration and participation, the analysis and reporting of this data would not have been possible.

\section{Conflict of interest}

None.

\section{Funding}

This work was supported by the Public Health Agency of Canada.

\section{Disclaimer}

This article was prepared using data from IMS Health Canada Inc. The analyses, conclusions, opinions, and statements expressed are those of the authors and not those of IMS Health Canada Inc.

\section{References}

(1) Public Health Agency of Canada (PHAC). Canadian Integrated Program for Antimicrobial Resistance Surveillance (CIPARS) 2011-Antimicrobial Resistance Short Report. Guelph, ON: PHAC; 2012. http://publications.gc.ca/collections/collection_2013/aspc-phac/HP2-4-2-2011-eng.pdf 